\title{
Sufi Visionary of Ottoman Damascus. 'Abd al-Ghanī al-Nābulusī 1641-1731. London - New York, Routledge Curzon, 2005, xii-172 p.
}

Alexandre Papas

\section{(2) OpenEdition}

1 Journals

\section{Édition électronique}

URL : http://journals.openedition.org/abstractairanica/13252

DOI : 10.4000/abstractairanica.13252

ISSN : 1961-960X

Éditeur :

CNRS (UMR 7528 Mondes iraniens et indiens), Éditions de l'IFRI

\section{Édition imprimée}

Date de publication : 15 mai 2007

ISSN : 0240-8910

Référence électronique

Alexandre Papas, «Sufi Visionary of Ottoman Damascus. 'Abd al-Ghanī al-Nābulusī 1641-1731.

London - New York, Routledge Curzon, 2005, xii-172 p. », Abstracta Iranica [En ligne], Volume 28 | 2007, document 294, mis en ligne le 18 septembre 2007, consulté le 25 septembre 2020. URL : http:// journals.openedition.org/abstractairanica/13252; DOI : https://doi.org/10.4000/abstractairanica. 13252

Ce document a été généré automatiquement le 25 septembre 2020.

Tous droits réservés 


\title{
Sufi Visionary of Ottoman
} Damascus. 'Abd al-Ghanī al-Nābulusī 1641-1731. London - New York, Routledge Curzon, 2005, xii-172 p.

\author{
Alexandre Papas
}

Ce livre est une introduction passionnante au grand maître soufi 'Abd al-Ghanī alNābulusī. Son originalité est de suivre la biographie du shaykh damascène tout en analysant son cheminement mystique et doctrinal. En sept chapitres, l'A. étudie ce parcours singulier sur trois échelles différentes : la culture soufie dans le Moyen-Orient ottoman; le parcours physique et mystique d'un de ses plus grands représentants; l'intimité de ses spéculations en même temps que leur postérité écrite. Partant, on peut retenir, parmi d'autres, plusieurs moments clés qui manifestent ces trois échelles: d'abord l'année 1664, au cours de laquelle Nābulusī alors dans une crise mystique compose son poème Nasamāt al-ashar fi madh al-nabĩ al-muHtār et sa glose, puis fait le voyage à Istanbul, en pleine période de controverse avec les Kādīizādelī, tout en étant initié à la Qādiriyya en cours de route. Autre moment, 1676 marque son initiation à la Naqšbandiyya par un shaykh de la branche centre-asiatique ahrārī ; Nābulusī se lie immédiatement après à la branche indienne mujaddidī, laquelle va progressivement symboliser la défense du sunnisme en Orient musulman. Il compose alors deux traités de défense du samā' (à l'instar d'autres Naqšbandī, notons-le) et accomplit une retraite spirituelle de sept ans qui correspondent à une période d'intense production écrite (dont le fameux Ta'tịir al-anām fì ta'bir al-manām). Citons enfin les années 1689-1700 pendant lesquelles le shaykh entreprend ses grands pèlerinages mystiques en Syrie même, vers le Mont Liban, Balbek, la Palestine et Jérusalem, bien sûr le Hijāz via Gaza et l'Égypte, enfin Tripoli. Ces pérégrinations consistent en visites aux saints inhumés ou vivants, séjours dans les zāwiya et fréquentations des milieux politiques. Ils représentent donc une activité du shaykh particulièrement dense et polyvalente, et aboutissent à la composition de plusieurs rihla qui renouvellent le genre viatique dans le sens d'une quête mystique. En somme, c'est toute la complexité et la maturation de 
Nābulusī qui se profilent dans cet ouvrage, bien au-delà du seul héritage akbarien auquel on le réduit parfois.

INDEX

Thèmes : 8 . Soufisme

AUTEURS

ALEXANDRE PAPAS

EHESS - Paris 